\title{
Kant's Critical Hermeneutic of Prayer
}

\section{Stephen R. Palmquist / Hong Kong Baptist \\ University}

\section{PRAYER IN PERSPECTIVE: THE COPERNICAN REVOLUTION IN RELIGION}

This essay is a systematic exposition and partial defense of Kant's philosophy of prayer.'

Such a bold statement is likely to surprise some readers. A typical response might be: "I didn't know Kant had a philosophy of prayer!" Those who are familiar with Kant's writings on religion are more likely to respond by assuming the content of what follows will be entirely negative. For on the rare occasions when commentators refer to Kant's views on prayer, they tend to depict his position as one that aims to render prayer superfluous to the practice of "true religion." ${ }^{2}$ Webb, for instance, claims Kant condemned "a supposed personal intercourse with God in prayer" as "a harmful and demoralizing self-illusion." There is undoubtedly some truth to this conventional portrayal of Kant's position: as we shall see, it is not difficult to find passages where Kant comes down hard on

' Much of what follows is based on material from two talks I gave on similar topics: "Kant's Philosophy of Prayer," for the Erasmus Society at Westmont College, Santa Barbara, on September 8, 1995, and "Why Should We Pray? An Examination and Critique of Kant's Views on Prayer," for a colloquium of the Department of Religion and Philosophy at Hong Kong Baptist University, on November 16, 1995. I would like to thank the many people who contributed comments and questions on those two occasions. Without their input, this article would have been considerably less clear.

2 Kant uses phrases such as "true religion" and "true church" on a number of occasions throughout his principal book on religion, Religion within the Bounds of Bare Reason-hereafter Religion. (Quotes from Religion are taken from the translation of T. M. Greene and H. H. I Iudson, published under the misleading title Religion wilhin the Limils of Reason Alone [New York: Harper \& Row, 1960]. For an explanation and defense of my way of translating the title, see "Does Kant Reduce Religion to Morality?" Kant-Studien 83, no. 2 [1992]: 129-48.) As I have argued elsewhere (see especially ibid.), such phrases designate not the abstract ideal of "moral" (or "pure") religion but, rather, any real-life manifestations of religion that embrace reason's pure moral religion as their core element (see, e.g., Religion, p. 115 (106)). Note that references to Kant's works will cite the pagination of the relevant volume of the Berlin Academy edition, with the English pagination being given in parentheses only for translations that do not specify the former, such as Religion.

${ }^{3}$ Clement C. J. Webb, Kant's Philosophy of Religion (Oxford: Clarendon, 1926), p. 20.

( 1997 by The University of Chicago. All rights reserved. 0022-4189/97/7704-0004\$02.00 
those for whom prayer is a means of manipulating God and/or avoiding personal responsibility. But is there another side to prayer that Kant regards as more palatable, if not necessary, to the practice of true religion?

The affirmative answer I shall give to this question in the following pages cannot be adequately understood without setting Kant's view of prayer against the background of his overall theory of religion. The key point - often overlooked or only dimly perceived in the standard interpretations of Kant's position-is that his "Copernican revolution" in philosophy applies just as much to his theory of religion as it does to his epistemology. ${ }^{4}$ In a nutshell, this revolution is the hypothesis that, when it comes to doing transcendental philosophy, the subject plays the active role in determining our knowledge (as concerns its form), while the object (as concerns the matter) plays a passive role. This new, "transcendental perspective" does not contradict our ordinary, empirical way of interpreting the world. On the contrary, Kant believes it provides the only possible justification for its trustworthiness: only the "transcendental idealist" can be a genuine "empirical realist." ${ }^{5}$ The same holds true for all Kant's applications of the Copernican revolution, including its application to religion. We must therefore keep in mind throughout this essay that statements intended to serve as transcendental foundations might at first (if interpreted without an awareness of their perspectival character) appear to contradict the very thing they are attempting to justify.

As applied to religion, the Copernican revolution implies that the philosopher's abstract formulation of "pure rational religion" will at one and the same time provide the necessary conditions for the possibility of genuine empirical religion and yet also manifest characteristics that appear to stand in opposition to the latter. Such opposition, however, need not be regarded as a contradiction, provided we interpret it in terms of the principle of perspective. Consider a typical, but important, example. Kant starts a new section of Book 4 by formulating the following principle: 6

\section{$\$ 2$ The Moral Principle of Religion Opposed to the Religious Illusion}

To begin with, I take the following proposition to be a principle requiring no proof: Whatever, over and above good life-conduct, man fancies that he can do to become well-pleasing to God is mere religious illusion and pseudo-service of God. I say, what man believes that he can do; for here it is not denied that beyond all that we can do there may be something in the mysteries of the highest wisdom that God alone can do to transform us into men well-pleasing to Him.

- For a fuller explanation of the Copernican revolution as it relates to Kant's epistemology, see sec. III.1 of my book, Kant's System of Perspectives (Lanham, Md.: University Press of America, 1993).

5 Immanuel Kant's Critique of Pure Reason, trans. Norman Kemp Smith (London: Macmillan, 1929), p. A371; see also p. A375 and Palmquist, Kant's System of Perspectives, pp. 173-75.

${ }^{6}$ Religion, pp. 170-71 (158-59). 


\section{The Journal of Religion}

According to the standard, reductionist (monoperspectival) method of interpreting Kant's philosophy of religion, this principle is construed to be yet one more attempt on Kant's part to depict religion as nothing but good conduct in disguise. But is this what Kant is actually saying?

If we look again at this passage through the eyes of the Copernican hypothesis, it takes on an entirely new character. No longer must we read between the lines and assume that Kant was merely trying to please the king's censors when he admits that "there may be something ... God alone can do to transform us into men well-pleasing to Him." Instead of adopting this highly dubious, yet all-too-common hypothesis, we can take such surprising claims (scattered throughout the entirety of Religion) at face value, as an expression of the attitude permitted, if not mandated, by the transcendental boundaries Kant establishes for "pure religion." In other words, a perspectival interpretation of this passage enables us to recognize in it one of many passages where Kant treats empirical religion as a form of "false [or pseudo] religion" not ipso facto, but only when it oversteps its bounds by seeking to please God with actions that are "over and above good life-conduct."

This phrase "over and above" is a crucial one that deserves more attention. T. M. Greene and H. H. Hudson use it to translate Kant's term "ausser" (literally, "outside of"). By paraphrasing the literal meaning of this word, the translators have unfortunately obscured an important nuance that is conveyed by Kant's formulation of the principle in question. In the second edition Preface Kant compares his twofold task in Religion to two concentric circles: ${ }^{7}$ the core circle marks the boundary of the pure (i.e., transcendental) religion of moral reason, while the outer circle defines the area occupied by any historical religion that has this pure religion as its highest priority or true end. Kant's expressed reason for introducing this metaphor is to explain the "experiment" he intends to conduct throughout Religion: namely, he will examine the details of the Christian religion in hopes of determining to what extent they incorporate, or at least promote, the moral core of all true religion. The area of the wider circle that overlaps the inner circle represents those aspects of Christianity that explicitly incorporate aspects of the pure religion, while the area between the two circles represents those aspects that promote pure religion, even though they are not themselves explicitly moral. With this metaphor in mind, the connotation of the word ausser becomes clear. Kant is saying that any so-called religious action that lies "outside of" these two circles-that is, any action that neither incorporates nor promotes pure religion-and yet is believed by its practitioner to be an effec-

' Ibid., p. 12 (11). 
tive means of "becom[ing] well-pleasing to God," can be nothing other than "religious illusion and pseudo-service of God." This is a far cry from strict reductionism. ${ }^{8}$

Rather than denying that any nonmoral action can play a proper role in true religion, Kant's principle can now be seen to fulfill an entirely negative function: it guards against the illusion that arises when religious people see their actions as being entirely cut off from morality. The positive side of this coin is that when religious actions retain their link to the moral core of pure religion, they are thereby justified as legitimate clements in a true and healthy religious way of life, even if they lie between the two circles rather than within the core itself. This, then, is the essential feature of Kant's Copernican Perspective as it relates to religion: from the transcendental perspective, religion is "pure," so it can be virtually identified with morally good life conduct, yet from the empirical perspective, religion as we experience it is necessarily historical, so it is bound to include nonmoral elements that can (and should) lend support and vitality to the moral core. With this Copernican revolution in religion clearly in view, let us now turn our attention to Kant's philosophy of prayer.

\section{THE MORAL "SPIRIT" OF TRANSCENDENTAL PRAYER}

Although the term "transcendental" never appears in Religion, the observant reader familiar with Kant's three Critiques can see the concept operating throughout the entire book. Kant's decision not to employ the very term that best characterizes his philosophical approach (the so-called transcendental philosophy) is admittedly rather odd. ${ }^{9}$ It was probably due to his desire to make Religion palatable to the general reader, ${ }^{10}$ rather than to any notion that the arguments in this book somehow fall outside the realm of transcendental philosophy. Evidence for the transcendental character of Kant's basic arguments could be drawn from many aspects of his exposition. Perhaps the most important in his frequent use of the word "pure" (a close relative to "transcendental"). But a detailed demonstration of this point is beyond the scope of this paper." For our purposes it will suffice merely to assume that the various characteristics of Kant's "true religion" constitute, by virtue of their association with "pure reli-

${ }^{B}$ A much more detailed defense of this qualified nonreductionist interpretation is given in Palmquist, "Does Kant Reduce Religion to Morality?"

"He does, however, use various other forms of the word "transcend" on eleven different occasions. See Religion, pp. 52 (48), 72 (66), 117 (107), 118 (108), 142 (133), 182 (170), 191 (179), 191 (180), 193 (182).

${ }^{10}$ See ibid., p. 14 (12-13).

"See chaps. 7 and 8 of my book, Kant's Critical Religion (Hong Kong: Philopsychy Press, in press). On the relation between "pure" and "transcendental," see Palmquist, Kant's Sy:tem of Perspectives, pp. 110-12. 
gion," the formal elements of a Critical (hence transcendental) standpoint on religion.

Prayer is no exception to the general rule that Kant is careful to distinguish between transcendental "fundamentals" and empirical "extras" in discussing every aspect of historical religious beliefs and actions. Indeed, he gives more attention to prayer than to any of the other three examples of standard ecclesiastical activities in the catalog of the latter given in the General Observation to Book 4 of Religion. This, I believe, is not because he was opposed to it more strongly but because he valued it more highly, perhaps because it is a form of service that is (or ought to be) inherently transcendental. Kant's formal definition of prayer contains both an empirical and a transcendental aspect. The former is expressed in terms of verbal messages spoken to God, and the latter in terms of a certain "spirit" that is to permeate the entirety of a religious person's life. He begins his 1,700-word excursus on prayer with the following two sentences: ${ }^{12}$

Praying, thought of as an inner formal service of God and hence as a means of grace, is a superstitious illusion (a fetish-making); for it is no more than a stated wish directed to a Being who needs no such information regarding the inner disposition of the wisher; therefore nothing is accomplished by it, and it discharges none of the duties to which, as commands of God, we are obligated; hence God is not really served. A heart-felt wish to be well-pleasing to God in our every act and abstention, or in other words, the disposition, accompanying all our actions, to perform these as though they were being executed in the service of God, is the spirit of prayer which can, and should, be present in us "without ceasing."

Without the benefit of a clear understanding of Kant's Copernican Perspective on religion, the first sentence in this passage would appear to be a straightforward universal condemnation of prayer as nothing but a wishfulfillment, "a superstitious illusion." Yet such a one-sided reductionist interpretation is too superficial to represent Kant's true intentions. Far from categorically denying the value of prayer, Kant is making an essentially hermeneutic point: the value of prayer depends on how the devotee interprets his or her actions. Only for those who interpret prayer "as an inner fornal service of God and hence as a means of grace" does it thereby become a form of false religion. Why is it false? Because the devotee in this case is detaching the act of praying from the moral core that gives it its ultimate value as a religious act. Instead of using prayer (an essentially nonmoral act) as a stimulus to live a better life, the devotee uses it as an excuse to avoid his or her genuine moral responsibilities, in the hope that prayers can stand in as a substitute for a moral life. This false interpreta-

${ }^{12}$ Religion, pp. 194-95 (182-83); cf. 1 Thess. 5:17. 
tion of prayer is without exception what Kant is condemning whenever he makes derogatory comments about the futility of prayer. ${ }^{13}$

Kantian Critique is never negative without offering an equal and opposite positive perspective as a complement, and Kant's view of prayer is no exception. In the second sentence quoted above, Kant defines "the spirit of prayer" as the "heart-felt wish to be well-pleasing to God in our every act and abstention, or in other words, the disposition, accompanying all our actions." 14 Whereas the first sentence emphasizes the empirical act of stating a wish, the emphasis has now shifted to the transcendental disposition, via the moral feeling of respect for God's commands. In other words, Kant is suggesting that the true heart (or pure core) of all prayer is an internal, dispositional spirit, not an external, verbal construction. Much the same point is made in a number of related passages. Some: of these include an explicit (Copernican) attempt to save verbal, empirical prayer from utter meaninglessness by stressing its connection to the transcendental spirit of prayer:

The purpose of [verbal] prayer can only be to induce in us a moral disposition; its purpose can never be pragmatic, seeking the satisfaction of our wants. It should fan into flame the cinders of morality in the inner recesses of our heart. ${ }^{15}$

${ }^{13}$ A good example comes in Religion (n. 2 above), p. 176 (164): "We can indeed recognize a tremendous difference in manner, but not in principle ... between the wholly sensuous Wogulite who in the morning places the paw of a bearskin upon his head with the short prayer, 'Strike me not dead!' and the sublimated Puritan and Independent in Connecticut: for, as regards principle, they both belong to one and the same class, namely, the class of those who let their worship of God consist in what in itself can never make man better (in faith in certain statutory dogmas or celebration of certain arbitrary observances)." Even here, Kant balances such comments by affirming a better way to interpret prayer-one that is not "ausser" true religion. He continues: "Only those who mean to find the service of God solely in the disposition to good life-conduct distinguish themselves from those others, by virtue of having passed over to a wholly different principle and one which is far nobler than the other, the principle ... whereby they confess themselves members of an (invisible) church which includes within itself all right-thinking people and, by its essential nature, can alone be the true church universal." In a similar vein, Kant's deprecation of the religious person who tries to "anticipate his penalties by offering rueful self-inflicted penances ... . ; or else to mollify [God] with prayers and entreaties, or with formulas and confessions in which he claims to believe" (ibid., p. 77 (72)) is directed only against those who use such practices as a way of concealing an evil disposition, not against those who use the sime outward forms as a means of enhancing a moral life.

it Ibid., pp. 194-95 (183).

15 Immanuel Kant, Lectures on Elhics, trans. Louis Infield (London: Methuen, 1930), p. (99)-hereafter Ethics. (Note that this version of Kant's lectures does not have corresponding page numbers in the Academy edition of Kant's works. All page numbers are therefore given in parentheses, referring only to the English translation.) This and the following quote are both part of a whole section of Ethics devoted to the topic of prayer (pp. (98-1C3)). That section and Religion, pp. 194-98 (182-86), constitute the two main texts for any attempt to interpret Kant's views on prayer. Since the Ethics passage is reconstructed from students' lecture notes and was not written by Kant himself, I am putting more weight. on the Religion passage. 
... The spirit of prayer is a devout and godly disposition. The letter is necessary to us only in order to awaken within us the spirit of prayer. ${ }^{16}$

Whether the devotee ... brings his formulas of prayer to the court of heaven with his lips, or by means of a prayer-wheel, like the Tibetan ... - whatever be substituted for the moral service of God, it is all one and all equal in value. What matters here is not a difference in the external form; everything depends upon the adoption or rejection of the unique principle of becoming well-pleasing to God-upon whether we rely on the moral disposition alone, so far as this disposition exhibits its vitality in actions which are its appearances, or on pious playthings and on inaction. ${ }^{17}$

Such passages are totally misread when construed as attempts to expunge prayer from the realm of true religion; for they actually highlight the importance of interpreting the two human perspectives on prayerthe empirical (or verbal) and the transcendental (or spiritual)-in their proper order of priority. Properly interpreting this order (i.e., identifying which element is the means and which is the end) is important not because one element is good and the other is bad but because both elements are good, yet one is better; subsuming the superior under the inferior good can hamper a person's moral growth. Thus, after again emphasizing the significance of priority, Kant exclaims: "So much depends, when we wish to unite two good things, upon the order in which they are united! True enlightenment lies in this very distinction; therein the service of God becomes first and foremost a free and hence a moral service." ${ }^{18}$ When we take into consideration this Copernican aspect of Kant's philosophy of religion, his purpose in the two passages quoted in the preceeding paragraph becomes clear: he is not trying to convince us to stop praying; rather, he is awakening us to a higher moral end or "spirit" that serves as the proper (though mysterious, and to a large extent, inexpressible) aim of all verbal prayer. To invert this priority by regarding the "letter" of prayer as an end in itself is to risk the total obstruction of prayer's pure religious core by a lesser, man-made "good." 19

${ }^{16}$ Ethics, p. (102).

${ }^{17}$ Religion, p. 173 (161).

${ }^{18}$ Ibid., p. 179 (167). One of the many passages that emphasize priority in this way refers explicitly both to prayer and to interpretation. On the issue of whether or not "prayer for revenge" is right on the grounds that the Psalms contain prayers of this type (ibid., p. 110n $(101 \mathrm{n})$ ), Kant replies by "rais[ing] the [hermeneutic] question as to whether morality should be expounded according to the Bible or whether the Bible should not rather by expounded according to morality:" Kant's answer, of course, would be the latter.

${ }^{19}$ Kant clarifies the spirit-letter relationship in the following two passages: "To perform an action ... without a good disposition is to comply with the letter of the law but not with its spirit" (Ethics, p. (47)). "The spirit of the moral law commands the disposition, its letter commands action" (ibid., p. (73)). 


\section{TIIE PARADOXICAL "LETTER" OF EMPIRICAL PRAYER}

Kant's views on the transcendental spirit of prayer require the empirical act of praying to be more than merely an illusion that is to be avoided at all cost. For Kant associates prayer with the very heart of all true religion: when properly interpreted by the practitioner, it serves to "fan into flame the cinders of morality in the inner recesses of the heart." ${ }^{20}$ Kant's complaint against prayer as it is commonly practiced is that an emphasis on the letter (i.e., on the words uttered) can often lead a person to hold the false belief that the uttering of such words is, in itself, pleasing to God. Kant treats all nonmoral religious activities in a similar way: they lead to false religion only if regarded as a direct way of serving God;21 if they are treated as an indirect form of service, intended "to induce in us a moral disposition," 22 then they are not only valid but can be vital to true religion. ${ }^{23} \mathrm{~A}$ similar point is made by the clothing-nakedness metaphor imbedded in the title of Religion (“... bare reason"). ${ }^{24}$ This metaphor also crops up on numerous occasions throughout Kant's exposition, including in his account of prayer. The dispositional "wish" to become a better person that defines the spirit of prayer is like a naked body (i.e., the true religious core of all genuine prayer), while the verbal expression of prayer is like clothing (i.e., the presentational form) that can be put on or taken off at will. ${ }^{25}$ With this additional hermeneutic and perspectival distinction at our disposal, we shall in this section examine more closely Kant's attitude toward the letter of prayer.

Thinking philosophically about the empirical practice of prayer inevitably leads, like metaphysical speculation concerning the ideas of God, freedom, and immortality, to paradoxical conclusions. Kant calls attention to one such paradox when he says: "If [a prayer] is to be heard, it must be made in faith. For if the practitioner has faith, he does not need to ask for it; but if he does not have faith, his petition cannot be heard." ${ }^{26}$ The paradox is heightened by Kant's insistence that only a prayer prayed in "the moral spirit of prayer ... can be prayed with faith, and by this faith we mean the assurance that the prayer will be heard." ${ }^{27}$ For if the

2n Ibid., p. (99).

21 Religion, pp. 103-6 (94-97).

${ }^{22}$ Ethics, p. (99).

${ }^{23}$ Religion (n. 2 above), p. $192(180-81)$.

${ }^{24}$ See $n$. 2 above.

${ }^{2 s}$ See Religion, pp. 195 (183), 197n (185n); Elhics, pp. (98, 100).

${ }^{26}$ Immanuel Kant, The Confict of the Faculties, trans. Mary J. Gregor (New York: Ab:aris, 1979), p. 10; cf. p. 56 .

${ }^{27}$ Religion, p. 196n (184n). 


\section{The Journal of Religion}

spirit of prayer is nonverbal, how can it be heard? Anyone who thinks of prayer solely in terms of its verbal expression is likely to assume Kant's point here is to force religious believers into a "catch-22" situation, where all prayer is a meaningless waste of time: as soon as you open your mouth, you are testifying to your lack of faith in God, so always resist the temptation to pray! Kant's Copernican Perspective, however, mandates a radically different interpretation of his intent. Such paradoxes, especially when formally elaborated in terms of antinomies, function as a Critical means of disciplining our reason to look beyond the theoretical standpoint (i.e., pure logic) to the practical standpoint (i.e., morality). If we keep in mind that "prayer" for Kant designates most fundamentally a moral-spiritual disposition, then we can recognize in this paradox a profound acknowledgment of the mysterious practical connection between the spirit and the letter of prayer.

Kant provides a more detailed explanation of the "paradoxical" nature of prayer in his Lectures on Ethics, where he assigns a genuine purpose to verbal prayer by explaining how it can serve as a means to a moral end:28

Objectively, prayer is certainly not necessary. ... Subjectively, however, prayer is necessary.

... It is a weakness in man that to give his thoughts expression he must put them into words. ... Those whose minds are practised in harbouring Ideas and dispositions can discard the aid of words and formal expression. Subtract these from prayer, and what remains? Only the spirit of prayer, the sense of devotion, the guide-line leading the heart to God by way of faith.... It is the spirit of the prayer alone which matters.

... Thus, prayers are not to be regarded as a special way of serving God, but only as a means of awakening within us the spirit of devotion. We do not serve God with words, ceremonies and gestures: we serve Him only by actions which reflect our devotion to Him.

... Prayer [as verbally expressed] appears to be a presumptuous act and an act of distrust in God. It seems to imply distrust in God's knowledge of what is good for us.... [Hence] the object of the prayer must be general and not particular.

... In faith we can only pray to be made worthy of God's goodness. In this respect we can believe with assurance that God will hear our prayers.

Here we see clearly that verbal prayer is not entirely meaningless. Rather, its purpose is to compensate for an inevitable weakness in human nature: as creatures of sensibility, we must express the dispositional (wordless) essence of prayer in an outward form (words) in order to wake up our

${ }^{28}$ Ethics (n. 15 above), pp. (98-102). 
moral disposition. This weakness is ours, not God's (whose "all-seeing eye penetrates into our innermost souls and reads our thoughts"), ${ }^{29}$ so we must always keep in mind that in uttering a verbal prayer we are not serving God, but ourselves. That is, we are testifying to our lack of awareness of our own disposition, and/or our inability to trust wholeheartedly that God will honor this disposition. If the devotee prays with this in mind-that is, if the letter is not viewed as the end, but as the means to a spiritual awakening-then Kant has no objections to the use of verbal prayer.

The problem, of course, is that, in an effort to hide this natural weakness, those who engage in verbal prayer tend to interpret their self-help as if it were intrinsically pleasing to God. Verbal prayer then becomes an end in itself. When this happens, it actually obstructs the person's moralspiritual growth and alienates the prayer from its true dispositional spirit. This is why Kant says: "It is the spirit of the prayer alone which matters." The letter only "matters" in the purely functional sense of producing a desired result; no particular verbal formulation can claim to "marter" more than another, provided they both awaken the moral disposition within. (This is why Kant recommends praying in generalities rather than specifics.) As religious believers grow more and more mature, their dependence on verbal prayer ought to decrease, until they "can discarcl the aid of words and formal expression." The fact that "those whose minds are practised in harbouring Ideas and dispositions" (i.e., philosophers and morally minded mystics, respectively) can readily do this does not mean it is possible (or even advisable) for everyone, at any stage of religious development, to discard verbal prayer. ${ }^{30}$ On the contrary, Kant is elsewhere very clear about the fact that phrases such as "can discard" do

\footnotetext{
q9 Ibid., p. (98).
}

${ }^{30}$ Kant likewise says in Religion, p. 197 (185), that "not all men stand in need of this means (of conversing within and really urth oneself, but ostensibly of speaking the more intell gibly with $\mathrm{God}$ )." This negative statement clearly implies that some people do stand in need of such a means. Kani's parenthetical remark should not be taken merely as a sarcastio jibe poking fun at anyone who is foolish enough to believe prayer enables them to commuricate with God; while he would no doubt be reluctant to interpret prayer in the literal way many religious believers do (to the extent that he claims people who do interpret prayer in this way cannot be entirely sincere and draw's special attention to the embarrassment and confusion experienced by a person who is found by others to be engaged "in behavior indicative of prayer" [ibid., p. 195n (183n)]), Kant himself does assume in numerous other passages that prayer has some authentically communicative aspect. His point here is more subtle and must be interpreted in light of his conviction that God is best conceived as living within us, so that the line between getting to know God and getting to know one's own true self cannot be clearly demarcated. Indeed. Kant's whole philosophy can be regarded as the elaboration and defense of a new, morally sensitive or "Critical" mysticism, as I have argued throug, hout Part 4 of my forthcoming book, Kant's Critical Religion (n. 11 above). 


\section{The Journal of Religion}

not indicate that the verbal expression must cease, but only "that it be able to cease" in appropriate situations. ${ }^{3 !}$

In light of this evidence that Kant did see a genuine purpose and function for verbal prayer, we must guard against the tendency to assume that he wished to grasp only one side of the paradox of prayer. In order to clarify his true intentions, let us reconstruct the paradox in terms of a full-fledged antinomy, as follows:

1. THesis. The verbal expression of prayer is necessary; prayer could not be genuine if it were to cease.

ProOF. Human nature consists of both sensibility and rationality. Rational constructs cannot have a meaningful content unless they relate to something sensible. Prayer is a rational construct that is intended to be heard by a higher Being. In order to be heard, and thus to be put to use in a meaningful way, prayer must be expressed in a sensible form - that is, in words. Since words carry meanings with them, all other aspects of prayer could cease; as long as the words remain, the prayer will carry a genuine meaning. Praying with faith means believing God will hear and understand one's words.

2. ANTITHesis. The verbal expression of prayer is unnecessary; it must cease in order for prayer to be genuine.

Proof. A prayer prayed without faith will not be heard by God. But a person with genuine faith believes God will already do exactly what is needed in every situation. The purpose of using words to express one's prayer is to tell God what is needed in a given situation. As such; verbal prayer is inevitably a sign of faithlessness and cannot be genuine. God sees and judges according to a person's moral disposition. A good disposition is therefore the true spirit of prayer. Words will only cloud the purity of this disposition and must be eliminated in order for prayer to be genuine.

Like all antinomies, this parallel exposition of two opposing arguments is intended to demonstrate that, as long as the subject (prayer) is analyzed from the theoretical standpoint alone, there is no way out of the paradox. Kant's position is perhaps closer to the Antithesis than to the Thesis in the above example; but in the end he would not want to accept either conclusion as definitive, for each side contains aspects of prayer that the

s1 Kant makes this point most clearly in reference to historical faith. In a pair of footnotes in Religion, p. 135 (126), he interprets the biblical statement that "God is all in all" (1 Cor. 15:26) "to mean that historical faith ... will itself cease and pass over into a pure religious faith. ... To this end we ought even now to labor industriously, by way of continuously setting free the pure religion from its present shell, which as yet cannot be spared." In the second edition, Kant added a second footnote to the end of this first footnote: "Not that it is to cease (for as a vehicle it may perhaps always be useful and necessary) but that it be able to cease; whereby is indicated merely the inner stability of the pure moral faith." Kant makes the same point even more explicitly in Elhics, p. (102): "as man is sensuous and the religious appeal in his senses has its uses, it can be said that man can have no pure religion." 
Copernican Perspective enables us to preserve. Kant's method of resolving the dilemma is, as suggested above, to call attention to the pracitical interpretation of a prayer's function for a given devotee. By defining verbal prayer as a practical means directed toward the end of deepening the spirit of prayer, Kant synthesizes the two extremes: the spirit of prayer (like the Antithesis) is necessary but (unlike the Antithesis) insufficient, given the weakness of human nature; the letter of prayer (like the Thesis) is useful but (unlike the Thesis) cannot be the source of prayer's ultimate meaning. Kant's position, then, is that God will "hear" a verbal prayer as long as it truly is being used as a vehicle for the pure spirit of prayer.

In hopes of encouraging this moderate ("Critical") view of prayer, Kant recommends a number of specific guidelines as to how we ought to pray and interpret our verbal prayers. First, the way to overcome the aforementioned paradox (or antinomy) is to focus our prayers on dispositional issues: "In faith we can only pray to be made worthy of God's goodness. In this respect we can believe with assurance that God will hear our prayers." ${ }^{2}$ Such assurance results from the fact that becoming worthy is a necessarily cooperative effort between the moral agent and God, ${ }^{33}$ where a person's responsibility lies only on the human side. ${ }^{34}$ Along these lines Kant cites the following principle: "'It is not essential, and hence not necessary, for every one to know what God does or has done for his salvation;' but it is essential to know what man himself must do in order to become worthy of this assistance." ${ }^{35}$ Before God's assistance can do any good, "man must first make himself worthy to receive it" ${ }^{36}$-and this worthiness refers not to "doing good deeds" (a view often wrongly imputed to Kant) but to fostering a receptivity for goodness in one's disposition. A person who prays to become worthy of God's goodness is (or ought to be) conforming to this principle. For in uttering such a prayer, the person does

32 Ethics, p. (102), as quoted above.
"See, e.g., Religion (n. 2 above), pp. $44(40), 100-101$ (92).
st Kant emphasizes this responsibility and its relation to the efficacy of faith in ibid., p. 196n (184n): "It is ... not only a preposterous but also a presumptuous illusion to tiy to divine whether, through the persistent importunity of one's request, God cannot be diverted (to our present advantage) from the plan of His wisdom. Hence we cannot hold that any prayer which is for a non-moral object is sure to be heard, that is, we cannot pray for such an object in faith. Nay, more: even were the object indeed moral, but yet possible only through supernatural influence (or at least awaited by us from this source alone beciuse we do not wish to trouble ourselves to bring it about - as, for example, the change of he:art, the putting on of the new man, called rebirth) it is at least so very uncertain that God will find it conformable to His wisclom to supplement in supernatural fashion our (selfincurred) deficiency that we have reason, rather, to expect the opposite. Man cannot therefore pray even for this in faith."

${ }^{55}$ Ibid., p. 52 (47).

sit Ibid., p. 44 (40). 


\section{The Journal of Religion}

not presume to know what God might do; the prayer serves rather to open the dispositional door that empowers a person to become more conscientious in doing good.

Notwithstanding his approval of prayers that will awaken our disposition to the reality of "God's goodness," Kant warns that verbally expressed prayer "can have no direct bearing upon the divine approval; and for this very reason it cannot be a duty for everyone." ${ }^{37}$ To regard verbal prayer "as a peculiar service of God and intrinsically good"-that is, even apart from its spirit- "is superstition." ${ }^{38}$ It does not please God in and of itself. Kant readily admits, however, that, like all aspects of pure religion, the spirit of prayer on its own is naked (bloss); so in order for it to be useful to universal religion, we often need "to clothe this wish ... in words and formulas"-an exercise that possesses value only as "a means whereby that disposition within us may be repeatedly quickened." ${ }^{30}$ As an example, Kant praises the special prayer Jesus taught his disciples for the way it expresses "the spirit of prayer most admirably in a formula." 40 It avoids superstition by being self-negating - that is, by "render[ing] dispensable ... the prayer itself (as a verbal utterance)." For "it contains no actual request for something which God in His wisdom might well refuse us, but simply a wish which, if it is genuine . . . of itself achieves its object (to become a man well-pleasing to God)." Kant approves of reciting the Lord's Prayer, then, on the grounds that it replaces the temptation to manipulate God with a spirit of humility that focuses our attention away from our words and toward our disposition. ${ }^{41}$

This example highlights another of Kant's Critical guidelines: the devout person should try to get along with as few words as possible, because "the letter" (as opposed to the spirit) of prayer "rather weakens the effect

s7 Ibid., pp. 196-97 (185).

${ }^{34}$ Ethics (n. 15 above), p. (101).

${ }^{39}$ Religion, pp. 195-96 (183-85).

${ }^{40}$ Ibid., p. 195n (183n); see Matt. 6:9-13.

"See also Ethics, p. (100). Along these lines, Kant advises that children be taught "set forms of prayer .... so that the language ... may possess here no value in itself but may be used merely to quicken the disposition to a course of life well-pleasing to God, those words being but an aid to the imagination" (Religion, p. 198 (186)). Incidentally, Kant justifies his positive assessment of the Lord's Prayer with the following hermeneutic twist (ibid., p. 195n (183-84n)): "Even the wish for the means of sustaining our existence (for bread) for one day, since this wish is expressly not directed to its continuance but is the effect of a felt need which is merely animal, is more a confession of what nature in us demands than a special deliberate request for what the man [in us] wills. The latter's request would be for bread for another day; but this is here clearly enough ruled out." In the next paragraph Kant admits that, although "morality in us gives rise to this assurance" that such a prayer will be heard, our confidence does not amount to absolute certainty: "for even were the petition to be for this day's bread alone, no one can be assured that it will be heard, i.e., that its granting stands in necessary conjunction with God's wisdom; it may perhaps comport better with this wisdom to let the suppliant die today for lack of bread." 
of the moral idea." 42 We should aim at the ideal of a form of contemplative prayer that remains entirely wordless, but like all ideals, the reality of any devout person's life is bound to include moments when words must be brought into play in order to fulfill the purpose of prayer-that is, "firmly to establish this [moral] goodness in ourselves, and repeatedly to awaken the disposition of goodness in the heart." ${ }^{43}$ Depending too much on the words used in formulating prayers can render it a false way of serving God. This can be avoided only when the prayer (like any of the "four observances of duty" discussed in the final General Observation of Religion) is "brought back to its spirit and its true meaning, namely, to a disposition dedicating itself to the kingdom of God within us and without us." 4.4

In keeping with the dispositional focus of all prayer, Kant insists elsewhere that verbal prayer must not be directed toward our own advantage: "We must never regard prayer as a means of getting our own way; if a prayer concerns our corporeal advantage, we ought to say it both with a trust in God's wisdom and with a submission to this wisdom. The greatest utility of prayer is indisputably a moral one, because through prayer both thankfulness and resignation toward God become effective in us." 45 Here again Kant emphasizes dispositional issues ("thankfulness and resignation toward God") and discourages any attempt to interpret prayer as a means of influencing God. As we saw in the previous section, a Critical attitude toward prayer interprets it as a tool by which "man seeks but to work upon himself," rather than "to work upon God." ${ }^{46}$ In order to abide by this hermeneutic principle, Kant suggests only prayers relating directly to good life conduct "can be categorical and unconditional: for other things I must pray conditionally." 47 Whereas uttering verbal prayers with a view toward influencing God takes for granted certain metaphysical dogmas about God's existence and nature, prayers that adopt this conditional, meditative spirit "can be offered with perfect sincerity even though the man praying does not presume to be able to affirm that the existence of God is wholly certain." 48 In this respect Kant's Critical

12 Religion, p. 197 (185).

13 Ibid., p. 193 (181).

4 Ibid., p. 192 (181).

15 Immanuel Kant, Lectures on Philosophical Theology, trans. A. W. Wood and G. M. C:lark (London: Cornell University Press, 1978), p. 155. It is important to note that, when Kant claims in Religion (n. 2 above), p. 197 (I85), that the quickening of the "spirit of prayer" will require "that the letter of it ... [must] finally fall away" he adds the following qualification in brackets: "at least as directed to our own advantage," thus implying that other forns of verbal prayer may well be wholly compatible with the spirit of prayer.

46 Religion, p. 195n (183n).

${ }^{17}$ Ethics, p. (100).

${ }^{48}$ Religion, p. $195 \mathrm{n}$ (183n). 


\section{The Journal of Religion}

hermeneutic of prayer provides an appropriately modest alternative to the Pharisee whose temple prayer Jesus condemned so pointedly. ${ }^{49}$ For the guidelines it establishes not only determine the minimum requirements necessary to insure that the use of verbal prayer will conform to the true spirit of prayer, but in so doing, they also embody a spirit of humility.

\section{CONTEMPLATION AND CRITIQUE: A FRAMEW'ORK FOR ASSESSING PRAYER}

Immanuel Kant was a man of prayer. This statement would be laughed out of court by many of the most accomplished and well-respected Kantscholars over the past two centuries. "Kant"-the man who complained about the nearby prison inmates whose noisy hymn singing disturbed his concentration - "a man of prayer? Preposterous!" Yet, in spite of the widely' accepted caricature of Kant as an essentially antircligious agnostic, the forgoing exposition of his Critical hermeneutic of prayer enables us to view such a formerly "preposterous" claim as plausible, if not probable. For Kant to call someone "a man of prayer" would mean such a person's life conduct is governed by the spirit of prayer. And this, in turn, means the person would need to have a "good disposition" (i.e., an intention to abide by the moral law at all times) and would need to regard that disposition as related in some way to a morally oriented Supreme Being. There is ample evidence that Kant himself qualifies as a man of prayer on both accounts. ${ }^{50}$

This conclusion, of course, does not commit us to the claim that the mature Kant actually engaged in verbal prayer on a regular basis. For he seems to be thinking of himself in the various passages we have considered, where he says philosophers (and others accustomed to working with ideas and dispositions) can totally dispense with verbal prayer. Kant's own bad childhood experiences with forced prayer in a religious school could have had something to do with his preference for a more contemplative

49 See Luke 18:10-14.

so Much of the relevant evidence is presented in chap. 10 of Palmquist, Kant's Critical Religion (n. 11 above). For our purposes a single example will suffice. In the Preface to Conflict (see $n .26$ above), Kant openly admits that, "when composing my writings, I have always pictured this judge as standing at my side to keep me not only from error that corrupts the soul, but even from any careless expression that might give offense. And ... now, in my seventy-first year, ... I can hardly help thinking that I may well have to answer for this very soon to a judge of the world who scrutinizes men's hearts" (pp. 9-10). With suitably broad parameters, this application of imagination could surely qualify as what might be called "imaging prayer." The need for belief in a Supreme Being is implied by Kant's very definition of religion (see, e.g., Religion, p. 153 (142)). 
form of prayer. ${ }^{51}$ In any case, our conclusion does require us to sec in Kant a person whose essential goal with respect to prayer was to preserve and uphold it as an essential and meaningful religious activity. The common assumption that in such passages in Religion he was merely trying to appease the governmental authorities (who had recently put out an edict outlawing the publication of ideas that spoke against the established state religion) must itself now be regarded as quite preposterous. For one thing, the government authorities were far from pleased with Kant's book! And rightly so, for they perceived the true motive of Religion, which was to weaken the power of ecclesiastical religion and replace it with a more authentic and effective alternative. Moreover, soon after the period of censorship ended, Kant repeated many of the same ideas, sometimes even more forcefully; in Part 1 of The Conflict of the Faculties.

That Kant himself actually believed in prayer as a form of wordless contemplation is suggested by numerous passages scattered throughout his works. Here it will suffice to mention just a few. ${ }^{32}$ Consider, for instance, the following moving passage, neatly tucked away in the middle of Kant's account of prayer in Religion: ${ }^{\mathbf{3}}$

The contemplation of the profound wisdom of the divine creation in the smallest things, and of its majesty in the great ... is a power which cannot only transport the mind into that sinking mood, called adoration, annihilating men, as it were, in their own eyes; it is also, in respect of its own moral determination, so soulelevating a power that words, in comparison, ... must needs pass away as empty sound because the emotion arising from such a vision of the hand of God is inexpressible. Men are prone ... to transform what really has reference solely to their own moral improvement into a courtly service, wherein the humiliations and glorifications usually are the less felt in a moral way the more volubly they are expressed.

It is difficult to imagine a person writings such words without having first practiced this kind of contemplation, without having seen the inexpressible vision referred to, and without having felt the emotion in the depths of his soul. This same "Critical mysticism," as I have called it, ${ }^{5.4}$ is evident when Kant warns that "even the attempts to attune the mind to the com. prehension of the idea of God, which is to be brought nearer to intuition" could produce "nothing but hypocritical veneration of God instead of a practical service of Him" if the feelings are given more weight than the

31 Willibald Klinke, Kant for Everyman, trans. Michael Bullock (London: Routledge \& Kegan Paul, 1952), pp. 17-20. Klinke reports (p. 19) that Kant once "told his friend Hippel, that looking back on that enslavement of youth filled him with terror and dread."

${ }^{32}$ See n. 50 above.

3s Religion, pp. 197-98 (185-86).

${ }^{3+}$ See n. 30 above. 
moral service they are meant to engender. ${ }^{55}$ For here he is not in any sense denying the legitimacy of such "devout attestations of awe." Once again, far from revealing an unbelieving skepticism, such comments must be read as making fine distinctions in a hermeneutic Critique. The word "even" attests to Kant's essentially positive attitude toward "attun[ing] the mind to ... God"; for such contemplation performs the crucial function of bringing "the idea of God ... nearer to intuition."

The purpose of this section is not to confirm or deny this historical point regarding Kant's contemplative inclinations; instead, our main task will be to assess his view of prayer. In particular, to what extent can Kant's Critical hermeneutic of prayer provide traditional religious believers with a viable way of interpreting their actions when they pray? At the end of his lengthy footnote on prayer, Kant gives a surprisingly affirmative assessment of the value of public prayer in a church: ${ }^{56}$

As regards the edification sought in attendance at church, here too public prayer is indeed no means of grace, yet it is a moral ceremony, whether it consists in united singing of the hymn of faith, or in the address formally directed to God, through the mouth of the clergyman and in the name of the whole congregation, and embracing all the moral concerns of men. Such an address, since it presents these last as a public concern, wherein the wish of each individual ought to be represented as united with the wishes of all toward the same ends (the ushering in of the kingdom of God), cannot only raise the feelings to the point of moral exaltation (whereas private prayers, because they are uttered without this sublime idea, lose little by little, through habituation, their influence upon the heart); it also possesses in itself a more rational basis than does private prayer for clothing the moral wish, which constitutes the spirit of prayer, in a formal mode of address. . . . For here there is a special purpose, namely, to set in more active motion the moral motivating forces of each individual through a public ceremony, representing the union of all men in a common desire for the kingdom of God; and this cannot be accomplished more appropriately than by speaking to the Head of this kingdom just as though He were specially present in that very place.

This passage is a good illustration of Kant's unusual preference for public prayer over private prayer. Like his preference for set prayers over spontaneous ones, this goes against the grain of many who were brought up to believe that a prayer's conceptual content must be kept at the forefront of the devotee's mind. Kant's position, by contrast, downplays this content, emphasizing instead that the main purpose of prayer is to awaken the disposition of each person who prays, not to change God's mind or perform some sort of miracle (though the possibility of these latter effects cannot, strictly speaking, be ruled out in advance). ${ }^{57}$

s5 Religion, p. 198 (186).

${ }^{36}$ Ibid., pp. 196-97n (185n).

${ }^{37}$ See ibid., p. 196n (184n). 
An important question raised by this passage, as by many of Kant's other comments on prayer, is whether or not the purposes he highlights are sufficient to justify all the forms of prayer practised by most religious believers. ${ }^{58}$ That Kant's hermeneutic supports morally attuned contemplative prayer can be taken as established. But what about more conventional, verbal prayers? Verbal prayers are often classified into five types: praise, thanksgiving, confession, petition, and supplication. Confession easily passes Kant's moral test, as long as it is uttered with a genuine intention to set right the crooked disposition that one is acknowledging to be at the root of one's sin. Kant himself mentions praise and thanksgiving as potentially serving to awaken and/or enhance a moral disposition, provided the person praying resists the temptation to interpret such prayers as intrinsically pleasing to God (and hence, as capable of taking the place of good life conduct). Petition and supplication, however, do not meet with such approval from Kant because of how readily they are interpreted as ways of manipulating God and because they do not seem to have any positive effect on one's own disposition. Despite Kant's own pessimism in this respect, is it possible to use Kant's Critical hermeneutic to justify even petition and supplication as legitimate forms of verbal prayer?

Before answering this question, we must note that Kant never outright denies that God hears prayers, nor does he deny that prayers can have an effect on external situations. Such denials, though often read "between the lines" by readers expecting strict reductionism, ${ }^{50}$ would contravene Kant's most basic Critical principles. For such claims are theoretical; as such, the proper philosophical response to them is agnosticism. Kant's position on the efficacy of prayer (had he stated it) would surely be in line with his (stated) positions on other theoretical religious issues: from "big" issues like the very existence of God to "small" issues like whether

${ }^{58} \mathrm{~A}$ passage that strongly suggests a negative answer comes in Religion (n. 2 above), p. 199 (187), where Kant says a church should contain "no formalities which might leac. to idolatry and so burden the conscience, e.g., certain prayers to God, with His infinite mercy personified under the name of a man." Although this seems to rule out praying in Je:us' name, the context shows that (as usual) Kant is not dogmatically denying the legitimacy of such a practice. Rather, he is making an essentially hermeneutic point: imagining one self as praying directly to the man, Jesus (especially when using an icon or other sensible representation for assistance) leads all to easily to the false attitude that this act is in itself efficacious and pleasing to God. Such an interpretation of one's mode of prayer leads directly to "idolatry" not the mode of prayer itself. Thus, the "illusion" Kant goes on to mention is one that views the church externally, as "a political commonwealth," rather than internally, as "the kingdom of God." That it would be possible to pray in Jesus' name without falling into such an illusion is, I believe, a possibility Kant would readily consider, especially in light of his highly suggestive discussion of the personified "archetype" of moral perfection (the pure rational religion's equivalent to Jesus) in the early pages of Book 2.

${ }^{39}$ See n. 2 above. 


\section{The Journal of Religion}

or not Jesus was "born of a virgin," we cannot definitely affirm or deny the claim from the theoretical standpoint; for this reason, the question must be passed over to the practical standpoint, so that we can determine whether or not there are good (moral) reasons to believe in spite of our inability to know with theoretical certainty.

When it comes to prayer, Kant's positive statements, as we have seen, all stress that prayer is rationally justifiable as long as it enhances the moral disposition of the person praying. But this cannot be taken to imply that, in situations where there is no significant influence on a person's disposition, prayer must be categorically rejected. On the contrary, such prayer is permissible, even though it is not positively justifiable, provided it does not obstruct the healthy operation of a person's moral disposition. There are, then, four discrete classifications implied by Kant's hermeneutic of religious activities. Each classification comes with a distinct mandate for the religious believer, as follows:

1. Religious actions/beliefs that are coextensive with the pure (moral) core of religion are necessary, though they may not be sufficient in a less-than-ideal world.

2. Religious actions/beliefs that lie outside the pure (moral) core, but actively serve to support and encourage morality, are not strictly necessary, provided some such assistance is available for anyone who needs a way to strengthen their weakness.

3. Religious actions/beliefs that lie outside the pure (moral) core and do not actively support or encourage morality are strictly optional, provided they do not obstruct a person's moral disposition.

4. Religious actions/beliefs that lie outside the pure (moral) core and do obstruct a person's moral disposition are false and must be actively discouraged.

Contemplative prayer and confession are (when properly employed) identical to the dispositional spirit of prayer, so they fall into the first class. The second class includes morally acceptable forms of praise and thanksgiving. The third, I believe, is where Kant would place petition and supplication. These are forms of prayer that are as significant to the goodness of a person's moral disposition as belief in (for example) the historicity of Adam and Eve are to the correctness of one's theological understanding. All three forms, when interpreted in terms of what Kant repeatedly calls the "religious illusion" (i.e., the hope that nonmoral actions can take the place of moral actions in God's eyes), fall into the fourth classification.

Numerous passages from the Bible could, in fact, be cited in support of Kant's view of prayer. Without going into the intricacies of biblical hermeneutics, I shall merely suggest the following correspondences. Mat- 
thew 6:5-8 teaches that words are of secondary importance (and can be counterproductive if overemphasized); inner communion with God is the key to prayer. Romans 8:26 suggests that the deepest form of prayer is a form of spiritual communion that takes place without any intelligible verbal expression. Mark 11:25 reminds us to reconcile our grudges before participating in public prayer. 2 Corinthians 13:9 takes this moral mandate even further by praying directly for "perfection." Mark 12:38-40 and Luke 18:10 are just two of the many passages that condemn those who use prayer as a form of self-aggrandizement or to cover up one's own evil disposition. The well-known mandate of 1 Thess. 5:17, that we should "pray without ceasing," could refer to a constant conversation with God (as is often assumed), but it could just as well refer (as Kant interpreted it) to an abiding spiritual disposition, thus saving it from being reduced to a potentially meaningless, neurotic babble. Matthew 21:22 makes a direct connection between faith and the efficacy of prayer (though Kant's explanation of how this is possible is admittedly rather unorthodox). And James 5:16 associates prayer's efficacy directly with the moral character of the person praying. All of these passages, and many others like them, reveal a surprising degree of overlap between Kant's Critical hermeneutic of prayer and biblical (or at least, New Testament) views on prayer.

Naturally, there are also some important differences. The Bible merely assumes that prayer is directed toward God, whereas Kant believes philosophers should remain agnostic about such theoretical questions. The Bible conveys numerous examples of prayers that Kant would regard as, at best, religiously neutral and at worst, positively detrimental to the moral character of the devotee. ${ }^{60}$ Biblical prayer is typically expressed in the confident terms of the imperative voice, whereas Kant speaks of prayer more cautiously in terms of a "wish." The main difference, though, is that in the Bible prayer and worship tend to be viewed as the focal point of one's religious life, with good life conduct following on it as an effect or "fruit" of one's relationship with God, whereas exactly the opposite is true for Kant's position.

In the end, this hermeneutic point is surely the most significant difference between conventional religious views on prayer and Kant's Critical position: it marks a difference of emphasis in one's interpretation of what is actually happening during the act of praying. It is perhaps inevitable for ordinary devotees to interpret their prayers literally, as acts directed toward God that form the focal point of their religion. Kant, in direct contrast to this approach, treats the internal, moral, and symbolic aspects

${ }^{60}$ See, e.g., Psalm 59:11-16; cf. Religion, p. 110n (101n). 


\section{The Journal of Religion}

of the prayer as essential, viewing the others as, at best, means to a moral end. Is Kant's position, then, in opposition to that of the ordinary believer after all? Only if we forget the nature and significance of the Copernican Perspective outlined in Section I. In the first edition Preface to Religion, Kant himself expresses his hope that "the Biblical theologian" might "be at one with the philosopher," despite their naturally opposing starting points (i.e., revelation and reason, respectively). ${ }^{61}$ The perspectival character of Kant's hermeneutic method therefore entails that the special, transcendental critique of prayer is intended not to do away with the time-honored way of understanding religion but to complement it by establishing prayer once and for all as a philosophically justifiable act.

${ }^{61}$ Religion, p. 10 (10). On Easter Sunday, 1996, just before completing this article, I attended an Anglican church in Hong Kong. The prayers, jointly led that day by a family from the congregation (and used here by permission), provided an excellent case study for a Kantian interpretation of prayer. From the first words ("Loving Father") to the last, every part of the prayer served to awaken the moral spirit of love and self-sacrifice in the dispositions of all who listened. After a few stimulating words of praise and thanksgiving, the father set the scene by announcing that we would "pray for our world, our community, and ourselves" and by asking that we be given God's disposition in these matters ("to see the world through your eyes ..."). One daughter then prayed for the poor, asking for God's intervention, then adding: "Show us what we can do to help this happen." The mother followed with a prayer for orphans and those who work with orphans, including the petition: "We pray that people's eyes would be opened to see the need and their hearts would be moved to action." After the father prayed "for Hong Kong at this time of uncertainty," asking for wisdom to be given to the leaders, the second daughter prayed "for the street sleepers and prisoners in Hong Kong that we would be generous towards them." The son then asked God to "help us to be quick to say sorry" and "to love one another." Following a time of silent prayer, the second daughter closed with a brief reminder of the meaning of Easter. Of course, any of these prayers could be improperly used as an excuse not to be improve one's life conduct, to wait instead for God to do the changing. However, that would be contrary to their obvious intent, which was to stir the hearts of all who prayed along. Kant might not have been able to affirm some of the more doctrinal statements included in the prayers offered on that day, but he undoubtedly would have acknowledged that the exercise as a whole could be readily justified philosophically because of its clear moral content. Likewise, the theological beliefs of the family saying those prayers prevent them from appreciating Kant's reasons for maintaining an agnostic position on various theoretical issues, but they would certainly appreciate and affirm his concern that prayers must not be used to conceal lazy or immoral life conduct. This, it seems, is a living example of what Kant meant when he encouraged the two sides to be "at one." 